\title{
Social Capital: Cross-industry and Cross-state Comparison among Malaysian Women Micro-entrepreneurs
}

\author{
Rajennd A/L Muniady 1 \\ Abdullah Al Mamun² \\ P. Yukthamarani Permarupan ${ }^{3}$ \\ Noor Raihani Binti Zainol ${ }^{3}$ \\ Mohd. Rosli Mohamad ${ }^{4}$ \\ ${ }^{1}$ Graduate Student, Faculty of Entrepreneurship and Business, Universiti Malaysia Kelantan \\ ${ }^{2}$ Senior Lecturer, Faculty of Entrepreneurship and Business, Universiti Malaysia Kelantan \\ ${ }^{3}$ Lecturer, Faculty of Entrepreneurship and Business, Universiti Malaysia Kelantan \\ ${ }^{4}$ Professor, Faculty of Entrepreneurship and Business, Universiti Malaysia Kelantan \\ "Corresponding Author, Email: abdullah.a@umk.edu.my
}

Doi:10.5901/mjss.2016.v7n1p350

Abstract

The objective of this study is to determine the distribution of social capital across industries and states in Peninsular Malaysia, since social capital is considered one of the key factors that contribute to the performance of micro-enterprises. This study employs the cross-sectional approach and quantitative data were collected through structured interviews from 417 women micro-entrepreneurs in Peninsular Malaysia. It was found that the distribution of social capital is the same across industries except for 'shared meaning and interpretation' and 'cognitive social capital'. However, findings reported a significant difference in items of social capital among the states, except for 'network density'. Policy makers should therefore focus on interactive programs in order to increase the social capital of the states with a low level of social capital as social capital is linked to enterprise performance and economic development.

Keywords: Social Capital; Cross-Industry; Cross-State; Micro-Enterprise

\section{Introduction}

The term "social capital" indicates the resources that are available from and through personal and business networks. These personal and business networks generate resources, such as business opportunities, information, financial capital, ideas, leads, emotional support, trust, cooperation, and even goodwill. The term "social" in the social capital context explains that these resources belong to an individual while being part of a network of relationships (Baker, 2010). Bourdieu, a French sociologist, defined social capital as the sum of resources, actual or virtual, that are available to individuals or groups derived from strong network relationships built by mutual acquaintance and recognition (Gauntlett, 2011). Robert Putnam details that communities with a high level of civic engagement and social interaction have better means of governance, democracy, and economy (Hoffmann \& Putnam, 2003). The World Bank defines social capital as "the groups, networks, norms, and trust that people have available to them for productive purposes" (Narayan, Jones, \& Woolcock, 2003).

Moving beyond individualism, the resources generated by social capital is beneficial and improves personal and business success. At the individual level, networks help to land a job. Not all individuals secure jobs through "formal" methods such as advertisements and headhunters. The practice of finding a job through networking is promoted by counselors and outplacement consultants, and people tend to land better paying jobs that are satisfying and they stay longer at these jobs. People with better networks are reported to have better salaries and tend to be promoted faster (Baker, 2010). At the firm level, social capital helps in securing venture capital. Based on a survey sponsored by the U.S Small Business Administration on how new businesses and start-ups acquire venture capital, a staggering seventy-five percent of the new businesses and start-ups acquired financing through social networks of investors and capital seekers, such as friends, colleagues, acquaintances (Baker, 2010). At the same time, social capital is linked to advertising based 
on word-of-mouth marketing where this method has a better effect when personal recommendation and referrals lead to actual purchase decision.

Social capital is crucial to potential entrepreneurs who wish to embark on a start-up. The act of meeting other entrepreneurs and building good social capital is important for starting entrepreneurial activities. For potential entrepreneurs, joining business incubators and entrepreneurial support network is necessary to promote and strengthen entrepreneurship (Neira, Portela, Cancelo, \& Calvo, 2013). The same study by Neira, Portela, Cancelo, \& Calvo (2013) found that the situation changes after the early-stage entrepreneurial activity and consolidated entrepreneurship; once the entrepreneur has the business rolling, social trust stops to have an impact.

The Malaysian government has been focused on promoting entrepreneurs in the country through the center for instructors and advanced skills training. The entrepreneurs have been given skills and entrepreneur development trainings to improve and to seize opportunities from the job market. For business start-ups, a total of RM65 million was given to the Small Entrepreneur Fund to promote a sustainable economy. A Shariah-compliant SME financing fund of RM2 billion was allocated to strengthen and to promote small and medium enterprises (SMEs); it was carried out through 13 Islamic banks throughout the nation. Empirical studies on social capital have proven the positive effect of social capital on economic development and the standard of living (Bennet and Richardson 2005, Svendsen 2003). Gootaert (1998) suggests that social capital is the missing link in economic development. Social capital is known to bring in benefits such as reducing transaction cost, reducing systematic risk, and boost investment. This was the case when Percoco (2012) tested this hypothesis among Italian cities. It was noted that there was a correlation between entrepreneurship and social capital, although this cannot be generalized, it is applicable to the Italian scenario.

The groundbreaking contribution to the literature of social capital and growth heightened during the 1990s through the book Making Democracy Work by Putnam, Leonardi \& Nanetti, (1993). In this book, the authors found a positive and significant correlation between economic performance and social capital where the latter is measured by indicators such as the number of voluntary organizations, the number of newspaper readers, voter turnout at polls, and civic retardants. Following that, Helliwell \& Putnam (1999) used the same indicators of social capital to show that there is a positive impact in the long run on economic growth in the Italian provinces. Based on the importance of entrepreneurship, which contributes to the economy, and development of a country, research focusing on why a business fails to take off or does not sustain based on factors such as access to finance has been well established. Apart from that, the differences between men and women in starting and building a business are another area of focus in entrepreneurship (Buttner and Rosen, 1998). However, research focusing on women owned businesses and factors that affect them are still minimal (Hanafi, 2012).

Policymakers and scholars have started to accept that social capital is valid and relevant in adding value to communities and people. Thus, policymakers are finding ways to utilize the positive vibe of social capital to benefit communities and individuals in the economic sense. However, the gap remains where there is not much knowledge explaining social capital and its impact on entrepreneurship (Gailey, 2010). Apart from that, although researches by Tsai and Goshal (1998) and Casson and Giusta (2007) have repeatedly discussed the importance of networks in promoting entrepreneurship, there is not much literature concerning the contribution of networks linked to business sustainability (Tsai and Goshal, 1998). Even if there are studies on entrepreneurship and network, it is limited to a single industry (Schilling and Phelps, 2007) and the manufacturing industry is the favorite (Park, Shin and Kim, 2010).

Small and medium enterprises (SMEs) represent the majority of business establishments in Malaysia. They represent $97.3 \%$ of the total business establishments, which is a total of 645,136 SMEs. Malaysian SMEs are divided into five sectors, namely agriculture, mining and quarrying, manufacturing, construction, and services. Among the five sectors, the services sector has the largest number of establishments at 580,986 establishments or $90 \%$ of total SMEs. Mining and quarrying is noted to have the smallest number of establishments at 289 establishments or $0.1 \%$ of the total SMEs. In terms of gross output, the services sector is the highest contributor at RM 286, 640 million followed by the manufacturing sector at RM 194, 032 million. The lowest gross output is from mining and quarrying at RM 1,105 million. As for employment, the services sector provides employment to 2.6 million workers followed by the manufacturing sector at 0.7 million workers. The lowest employment is in mining and quarrying at 5.8 thousand (Department of Statistics, 2011).

In terms of size, most of the SMEs are micro sized. $77 \%$ of the total SMEs are micro establishments followed by 128,787 or $20.0 \%$ of small sized establishments and 19,891 or $3.0 \%$ of medium sized establishments. SMEs are categorized into micro, small and medium enterprises based on full-time employees and annual sales turnover. Based on full-time employees, a micro enterprise is defined as having less than 5 employees. A small enterprise is defined as having between 5 and 50 employees for manufacturing and between 5 and less than 20 employees for the other sectors. A medium enterprise is defined as having between 51 employees and 150 employees for manufacturing and between 20 
and 50 employees for the others sectors. Based on the annual sales turnover, micro enterprises are defined as making less than RM250, 000 in the manufacturing sector and less than RM 200,000 in the other sectors. Small establishments are defined as having an annual sales turnover of between RM 250, 000 and less than RM 10 million for manufacturing and between RM 200,000 and less than RM 1 million for the other sectors. It is considered a medium establishment when the annual sales turnover is between RM 10 million and RM 25 million for the manufacturing sector and between RM 1 million and RM 5 million for the other sectors (Department of Statistics, 2011).

In terms of distribution of SMEs by state, Selangor has the highest percentage of SMEs at 19.5\%, followed by the Federal Territory of Kuala Lumpur and Johor at $13.1 \%$ and $10.7 \%$, respectively. The Federal Territory of Putrajaya is noted as having the smallest percentage of SMEs at $0.1 \%$ followed by the Federal Territory of Labuan and the state of Perlis at $0.3 \%$ and $0.8 \%$, respectively (Department of Statistics, 2011). Given the importance of social capital to entrepreneurs, enterprises and the economic development of the county, this study is an effort to measure the distribution of social capital across industries and states. Empirical evidences suggest that high and equally distributed levels of social capital benefits the citizens and unequal distribution affects the economic development (Ponzetto and Troiano, 2014). A study by Fazio \& Lavecchia (2013) which used trust as a measure of social capital found that differences in social capital are evident both across countries and within a country. The distribution of social capital was noted to be different among European countries (Parts, 2013). New member states such as Bulgaria, Czech Republic, Estonia, Hungary, Latvia, Lithuania, Poland, Romania, Slovak Republic, and Slovenia have a lower level compared to Western European countries such as Austria, Belgium, Cyprus, Denmark, Finland, Germany, France, Greece, Iceland, Ireland, Italy, Luxembourg, Malta, Netherlands, Norway, Portugal, Spain, Sweden, Switzerland, and the Great Britain. However, an older research by Van Oorschot, Arts, and Gelissen (2006) found that there was no substantial difference in regards to social capital across European countries and regions except for Scandinavia where it was noted to be higher in social capital. As the formation of social capital is affected by the supportive environments and state government plays in crucial role in promoting micro-enterprises, this study therefore aimed to determine the distribution of social capital across the states in Peninsular Malaysia. This study also examined the distribution of social capital across the industry in Peninsular Malaysia. This study intended to provide a better understanding and empirical evidence on how social capital is distributed across industries and states in Malaysia.

\section{Literature Review}

The concept of social capital revolves around the effect and consequences of human interactions and connectedness, and how it is related to individuals and the social structure (Tzanakis, 2013). Social capital was even found in the disadvantaged African American community in the early 1990s. It was found that they used both traditional and nontraditional social capital to promote economic outcomes (Cook, 2011). In the case of women entrepreneurs, formal social capital is proven to bring in more benefits in terms of growth resources, such as financial resources, compared to informal social capital (Kickul, Gundry, and Sampson, 2007). It was found that training in production/operations and planning along with formal social capital was present among women entrepreneurs with high growth resources.

Recently, more academicians have recognized and agreed upon the benefits of social capital. Carey, Lawson, and Krause (2011) found significant benefits derived from the relationship between the buyer and the supplier of a company. Based on a sample of 163 respondents, relational social capital was found to mediate the link between cognitive and structural dimensions of social capital with performance which was measured as innovation. In the Chinese life insurance industry, social capital was proven to have a strong relationship with objective sales performance; Chen, Zhang, and Fey (2011) found that when HR practices did not improve performance, social capital came in as a moderator to push individual performance among 984 participants from China. In the less developed regions of the United Kingdom, the government was involved in providing entrepreneurship scholarship. In the study by Jayawarna, Jones, and Macpherson (2011) conducted to examine how nascent entrepreneurs performed, it was found that bootstrapping helped and social capital played a significant role in securing bootstrapped resources.

\subsection{Cognitive Social Capital}

The cognitive dimension refers to the resources that provide shared representations, interpretations, and systems of meaning among parties (Nahapiet and Ghoshal, 1998). This dimension, the least studied of the three, encompasses shared meanings and shared interpretations between parties in a relationship. The cognitive dimension captures the concepts of shared norms, systems of meanings and values, and, as such, we can expect the cognitive dimension to directly impact the development of social capital and the development of relationships. Nahapiet and Ghoshal (1998) 
suggest that cognitive capital is embodied in the shared visions and collective goals of organizational partners and is encapsulated by shared perceptions, expectations, and interpretations. Relationships developed with shared norms and values can be expected to be stronger (Moran, 2005). Weick et al. (1995) assert that when there is congruence of goals and values and when interpretations are shared by and across organizational partners, this cognitive capital becomes ongoing, cumulatively supportive, and self-reinforcing. The cognitive dimension reflects the concept that separate networks or communities develop unique terms, acronyms, interpretations of numbers, and concepts.

\subsection{Relational Social Capital}

The relational dimension concerns the kind of personal relationships that people have developed with each other through a history of interactions (Nahapiet and Ghoshal, 1998). This dimension encompasses the characteristics and qualities of individual relationships. Therefore, issues such as shared history, trust, respect, and friendship are important. The relational dimension is associated with the "qualities", good or bad of on-going relationships. The relational dimension encompasses the character and qualities of the connection between individuals. This is often characterized through trust and cooperation and the identification that a particular individual has within a network of relationships. An example of how the relational dimension may come into play can be seen when comparing the interactions between separate individuals who may have the same positions in a network of relationships (say a buyer and a supplier). Depending on the history of bonds and trustworthiness between the two individuals, the action and dynamics of the interactions will be very different if the same two people did not have any relational ties. The interaction between the individual actors is highly influenced by the relationship and history of exchanges between the particular individuals. This paper views the relational dimension concept as the assets created and leveraged through distinct (specific person-to-person) relationships that have their own unique relational history.

\subsection{Structural Social Capital}

The structural dimension concerns the properties of the social system and that of the network of relations as a whole (Nahapiet and Ghoshal, 1998). This dimension has been explored in depth and strongly influenced by the work of Burt (1992) and deals with whom you reach and how you reach them. The structural dimension encompasses network components and facets, such as the presence or absence of ties between parties, the configuration of a network (such as the hierarchy within an organization), and concepts, such as the density of relationships, structural holes in networks, the presence or absence of network ties between different people, formal and/or informal (such as appropriable networks) network configuration, and the density and connectivity of a network. According to Burt (1992), actors on opposite sides of structural holes operate in different information circles, and thus, there is value in spanning these separate information circles. Combining information from these separate, non-redundant information flows, then, offers the potential for innovation and the generation of new intellectual capital. We suggest here that these properties in and of themselves cannot generate social capital; rather these ties facilitate social capital only when they work in conjunction with the relational and cognitive dimensions. Structural ties alone cannot bridge separate information flows effectively, for, as Burt asserts, closure between two networks requires more than just structural ties; bridging also requires attributes such as facilitating trust, collaborative alignment, and shared interpretations (Burt, 1995).

\section{Methodology}

This study adopted a cross-sectional research design and collected quantitative data through structured interviews from registered women micro-entrepreneurs in Peninsular Malaysia. The sampling frame was based on the business directory of the SME Corporation of Malaysia's registered members of National Association of Women Entrepreneurs. Based on the list of registered women entrepreneurs under the SME Corporation of Malaysia, there are a total of 126,910 registered SMEs in Malaysia, owned by women entrepreneurs; among them, 111,571 are registered micro-enterprises. The micro-entrepreneurs were drawn from four different regions of Peninsular Malaysia, namely the Northern, Central, Southern, and the East Coast regions. The Northern region is made up of Perlis, Kedah Penang, and Perak. Kuala Lumpur and Selangor represents the Central region. The Southern region constitutes the states of Malacca and Johor while the East Coast region is made up of Kelantan, Terengganu, and Pahang. This research adopted the stratified random sampling method in order to identify women entrepreneurs from the four regions, which expected to represent the women micro-entrepreneurs in Peninsular Malaysia. This sampling method ensures that all sections of the population are taken into consideration. Each region was considered as strata; from that, a simple random sampling method was 
used to select 500 women micro-entrepreneurs, where every micro-entrepreneur had an equal chance of being selected. After retrieving the details of 500 women micro-entrepreneurs from a list of 111,571 women micro-entrepreneurs, this study confirmed their current status, size of enterprise (based on the total investment and number of full-time employment), and whether they fully own and manage their enterprise. Among the selected 500 micro-entrepreneurs, a total of 421 micro-entrepreneurs were selected based on their recent status (active, own, and manage) and size. Among them, only 4 women micro-entrepreneurs refused the request for an interview; therefore, the complete data were collected from 417 women micro-entrepreneurs.

\subsection{Research Instrument}

A questionnaire was designed using simple and unbiased wordings whereby respondents could easily understand the questions and provide answers based on their own perception. Questions were adopted from earlier studies with minor modifications where needed. Details of each section, what it measured and from whom this study adopted the questions are presented below. A five-point Likert scale ranging from 1 (strongly disagree) to 5 (strongly agree) was used. Cognitive dimension is the ease of communication among various actors in a day-to-day business activity. This was derived through shared meaning, shared interpretation, shared values, and shared norms. This study used a combination of questions (from Carey, Lawson, \& Krause, 2011) to measure shared meaning and interpretation, and shared values and norms, to represent micro-entrepreneurs' cognitive social capital. The structural dimension is a combination of network ties and network density, which allows resources and knowledge exchange by interacting in a social network. The questions to measure micro-entrepreneurs' network ties were adopted from Turner (2011), Mercy (2013), and Rochelle (2011), and for network density, all the measures were adopted from Elly (2010). Finally, the relational dimension measures the type of personal relationships people have built with each other through a chain of interactions. To measure the structural social capital, this study focused on the quality of relationship, and the level of trust among key business players. Measures for 'quality of business relationships' were adopted from Turner (2011), while measures for 'trust among key business players' were adopted from Turner (2011) and Koh (2010).

\section{Summary of Findings}

\subsection{Micro-entrepreneurs and micro-enterprises' characteristics}

In order to conduct a cross-state and cross-industry comparison on the distribution of social capital, this study collected quantitative data from a total of 417 micro-entrepreneurs from Malaysia. Among them, the highest proportion of women entrepreneurs is within the age group of 31 to $40(47 \%)$ followed by the age group of 41 to $50(25.2 \%)$. The lowest number of women entrepreneurs fall under the age group of below $20(0.5 \%)$. Out of the 417 respondents, $322(77.2 \%)$ are married and $66(15.8 \%)$ remain single. $16(3.6 \%)$ of them are divorced and $13(2.9 \%)$ are widowed.

Table 1. Micro-entrepreneurs and micro-enterprises' characteristics

\begin{tabular}{|c|c|c|c|c|c|}
\hline & $\mathrm{N}$ & $\%$ & & $\mathrm{~N}$ & $\%$ \\
\hline Marital Status & & & \multicolumn{3}{|l|}{ Age (Years) } \\
\hline Married & 322 & $77.2 \%$ & Below 20 & 2 & $0.5 \%$ \\
\hline Single & 66 & $15.8 \%$ & $20-30$ & 76 & $18.2 \%$ \\
\hline Divorced & 16 & $3.6 \%$ & $31-40$ & 196 & $47.0 \%$ \\
\hline Widowed & 13 & $2.9 \%$ & $41-50$ & 105 & $25.2 \%$ \\
\hline \multirow[t]{2}{*}{ Total } & 417 & $100 \%$ & More than 50 & 38 & $9.1 \%$ \\
\hline & & & Total & 417 & $100 \%$ \\
\hline \multicolumn{6}{|l|}{ Principal Decision Maker } \\
\hline Respondent & 132 & $31.7 \%$ & Education & & \\
\hline Spouse & 22 & $5.3 \%$ & Never attended school & 6 & $1.4 \%$ \\
\hline Respondent and Spouse & 257 & $61.6 \%$ & Primary school & 38 & $9.1 \%$ \\
\hline Other relatives & 6 & $1.4 \%$ & Secondary school & 162 & $38.8 \%$ \\
\hline \multirow[t]{2}{*}{ Total } & 417 & $100 \%$ & STPM/Diploma & 151 & $36.2 \%$ \\
\hline & & & Undergraduate Degree & 55 & $13.2 \%$ \\
\hline \multicolumn{3}{|c|}{ Management experience through earlier employment } & Masters Degree & 5 & $1.2 \%$ \\
\hline Yes & 91 & $21.8 \%$ & Total & 417 & $100 \%$ \\
\hline
\end{tabular}




\begin{tabular}{|c|c|c|c|c|c|}
\hline \multirow{2}{*}{ No } & \multirow[b]{2}{*}{326} & \multirow[b]{2}{*}{$78.2 \%$} & & & \\
\hline & & & & & \\
\hline Total & 417 & $100 \%$ & \multicolumn{3}{|l|}{ State } \\
\hline & & & Penang & 30 & $7.2 \%$ \\
\hline \multicolumn{3}{|c|}{ Starting in the same field as previous employment } & Perak & 33 & $7.5 \%$ \\
\hline Yes & 66 & $15.8 \%$ & Selangor & 62 & $14.1 \%$ \\
\hline No & 351 & $84.2 \%$ & Johor & 99 & $22.4 \%$ \\
\hline \multirow[t]{2}{*}{ Total } & 417 & $100 \%$ & Kelantan & 98 & $22.2 \%$ \\
\hline & & & Terengganu & 95 & $21.5 \%$ \\
\hline Established & & & Total & 417 & $100 \%$ \\
\hline $1-5$ Years ago & 118 & $28.3 \%$ & & & \\
\hline $5-10$ Years ago & 163 & $39.1 \%$ & Firm's main activity & & \\
\hline 10 - 15 Years ago & 93 & $22.3 \%$ & Manufacturing & 168 & $40.3 \%$ \\
\hline $15-20$ Years ago & 30 & $7.2 \%$ & Retailing & 131 & $31.4 \%$ \\
\hline $20-25$ Years ago & 2 & $0.5 \%$ & Wholesaler & 31 & $7.4 \%$ \\
\hline$>25$ Years ago & 11 & $2.6 \%$ & Agriculture & 1 & $0.2 \%$ \\
\hline \multirow[t]{2}{*}{ Total } & 417 & $100 \%$ & Services & 86 & $20.6 \%$ \\
\hline & & & Total & 417 & $100 \%$ \\
\hline
\end{tabular}

As per their educational background, a total of $162(38.8 \%)$ respondents have attended secondary school, followed by 151 (36.2\%) of them who have the Malaysian Higher School Certificate (STPM) or a Diploma, 5 (1.2\%) respondents have completed the masters' degree and only $6(1.4 \%)$ micro-entrepreneurs never attended school. Majority of the respondents, $257(61.6 \%)$, reported that they take all business decisions together with their spouse, while $132(31.7 \%)$ of them are the principal decision makers. About $6(1.4 \%)$ micro-entrepreneurs stated that other relatives are the principal decisions makers in their household. Among the micro-enterprises, the highest number of firms (168 or 40.3\%) are involved in manufacturing activities, followed by retailing (131 or 31.4\%), services (86 or 20.6\%), and only 1 is involved in the agricultural activity.

\subsection{Reliability analysis}

Cronbach's Alpha explains the indicators' inter-correlations which estimate the reliability for the indicators used. As presented in Table 2, Cronbach's Alpha values for all items, i.e. shared meaning and interpretation, shared value and norms, quality of business relationship, trust among key business players, length of business relations, network ties, network density, cognitive social capital, and social capital, are more than 0.7 except for trust among key business players with 0.638 , which means all the items are reliable.

Table 2. Reliability Analysis

\begin{tabular}{lcc}
\hline Variable & Cronbach's Alpha & N of Items \\
\hline Shared Meaning and Interpretation & .720 & 4 \\
Shared Values and Norms & .949 & 4 \\
Quality of Business Relationship & .812 & 6 \\
Trust among Key Business Players & .638 & 4 \\
Length of Business Relations & .864 & 4 \\
Network Ties & .764 & 7 \\
Network Density & .765 & 6 \\
Cognitive Social Capital & .913 & 5 \\
Social Capital & .908 & 35 \\
\hline
\end{tabular}

\subsection{Testing normality}

The Shapiro-Wilk's test $(p>.05)$ explains the normality of data distribution. Based on Table 3, the $p$ value for all items of social capital is less than .005 , which means that the data is not normally distributed. This study therefore used the nonparametric Independent-Samples-Kruskal-Wallis Test to test the hypotheses. 
Table 3. Tests of Normality

\begin{tabular}{lcccccc}
\hline & \multicolumn{3}{c}{ Kolmogorov-Smirnova } & \multicolumn{3}{c}{ Shapiro-Wilk } \\
& Statistic & df & Sig. & Statistic & df & Sig. \\
Shared meaning and interpretation & .247 & 417 & .000 & .874 & 417 & .000 \\
Shared values and norms & .184 & 417 & .000 & .874 & 417 & .000 \\
Quality of business relationship & .236 & 417 & .000 & .885 & 417 & .000 \\
Trust among key business players & .243 & 417 & .000 & .901 & 417 & .000 \\
Length of business relationships & .160 & 417 & .000 & .916 & 417 & .000 \\
Network ties & .201 & 417 & .000 & .933 & 417 & .000 \\
Network density & .136 & 417 & .000 & .955 & 417 & .000 \\
Cognitive Social Capital & .143 & 417 & .000 & .942 & 417 & .000 \\
Social Capital & .110 & 417 & .000 & .967 & 417 & .000 \\
\hline
\end{tabular}

This study has 16 hypotheses including 8 hypotheses testing the distribution of social capital across states in Malaysia and another 8 hypotheses testing the distribution of social capital across industries.

Table 4. Hypothesis Testing - Cross-Country

\begin{tabular}{|c|c|c|c|}
\hline \multirow{2}{*}{ Shared meaning and interpretation } & States & N Mean Std. D & Testing Mean Difference \\
\hline & $\begin{array}{l}\text { nPenang } \\
\text { Perak } \\
\text { Selangor } \\
\text { Johor } \\
\text { Kelantan } \\
\text { Terenggan }\end{array}$ & $\begin{array}{r}303.7833 .27647 \\
333.8409 .37924 \\
623.7782 .29374 \\
993.8434 .28702 \\
983.4719 .43209 \\
953.6921 .39352\end{array}$ & ndent-Samples-Kruskal-Wallis Test \\
\hline Shared values and norms & $\begin{array}{l}\text { Penang } \\
\text { Perak } \\
\text { Selangor } \\
\text { Johor } \\
\text { Kelantan } \\
\text { Terenggan }\end{array}$ & $\begin{array}{r}304.1250 .70634 \\
333.8864 .55583 \\
623.8468 .77665 \\
993.8788 .64421 \\
983.4566 .68491 \\
4953.8263 .61354\end{array}$ & $\begin{array}{l}\text { dent-Samples-Kruskal-Wallis Test } \\
\text { p value: } 0.000<0.05\end{array}$ \\
\hline Quality of business relationship & $\begin{array}{l}\text { Penang } \\
\text { Perak } \\
\text { Selangor } \\
\text { Johor } \\
\text { Kelantan } \\
\text { Terenggan }\end{array}$ & $\begin{array}{r}304.2111 .51404 \\
334.0101 .41235 \\
624.0672 .50450 \\
994.0269 .47721 \\
983.5680 .63941 \\
\text { u953.9140.52809 }\end{array}$ & $\begin{array}{l}\text { dent-Samples-Kruskal-Wallis Test } \\
\text { p value: } 0.000<0.05\end{array}$ \\
\hline Trust among key business players & $\begin{array}{l}\text { Penang } \\
\text { Perak } \\
\text { Selangor } \\
\text { Johor } \\
\text { Kelantan } \\
\text { Terenggan }\end{array}$ & $\begin{array}{r}303.8000 .53498 \\
333.7803 .47908 \\
623.6694 .44761 \\
993.8157 .50582 \\
983.4388 .55736 \\
\text { u953.6974.46542 }\end{array}$ & dent-Samples-Kruskal-Wallis Test \\
\hline Length of business relationships & $\begin{array}{l}\text { Penang } \\
\text { Perak } \\
\text { Selangor } \\
\text { Johor } \\
\text { Kelantan } \\
\text { Terenggan }\end{array}$ & $\begin{array}{r}304.0083 .52310 \\
333.7424 .77431 \\
623.9879 .46700 \\
993.7702 .65434 \\
983.4515 .84696 \\
953.7974 .63925\end{array}$ & $\begin{array}{l}\text { dent-Samples-Kruskal-Wallis Test } \\
\text { p value: } 0.000<0.05\end{array}$ \\
\hline Network ties & $\begin{array}{l}\text { Penang } \\
\text { Perak } \\
\text { Selangor } \\
\text { Johor } \\
\text { Kelantan } \\
\text { Terenggan } \\
\end{array}$ & $\begin{array}{r}304.0667 .46364 \\
333.9913 .41793 \\
624.0115 .40431 \\
994.0866 .43428 \\
983.8426 .58327 \\
\text { u953.8180.42677 }\end{array}$ & $\begin{array}{l}\text { dent-Samples-Kruskal-Wallis Test } \\
\text { p value: } 0.000<0.05\end{array}$ \\
\hline Network density & $\begin{array}{l}\text { Penang } \\
\text { Perak } \\
\text { Selangor }\end{array}$ & $\begin{array}{l}303.4056 .70803 \\
333.1111 .86569 \\
623.1425 .66997\end{array}$ & ndent-Samples-Kruskal-Wallis Test \\
\hline
\end{tabular}




\begin{tabular}{|c|c|c|c|}
\hline & $\begin{array}{l}\text { Johor } \\
\text { Kelantan } \\
\text { Terenggan }\end{array}$ & $\begin{array}{r}993.3316 .77719 \\
983.3435 .66916 \\
\text { u953.1947.68012 }\end{array}$ & Retain the null hypothesis \\
\hline \multirow[t]{4}{*}{ Cognitive social capital } & $\begin{array}{l}\text { Penang } \\
\text { Perak }\end{array}$ & \multicolumn{2}{|c|}{$\begin{array}{l}\text { 303.9542.42736 Independent-Samples-Kruskal-Wallis Tes } \\
\text { 333.8636.34989 }\end{array}$} \\
\hline & Selangor & $\begin{array}{l}623.8125 .48213 \\
993.861139322\end{array}$ & p value: $0.000<0.05$ \\
\hline & Kelantan & 983.4643 .49514 & \\
\hline & Terenggan & u953.7592.42653 & Reject tne null nypotnesis \\
\hline \multirow[t]{4}{*}{ Social capital } & $\begin{array}{l}\text { Penang } \\
\text { Perak }\end{array}$ & \multicolumn{2}{|c|}{$\begin{array}{l}\text { 303.8989.35262 Independent-Samples-Kruskal-Wallis Test } \\
\text { 333.7530.35171 }\end{array}$} \\
\hline & Selangor & 623.7659 .34814 & nvalue. 0 0 0005 \\
\hline & Johor & 993.8137 .35600 & $p$ value. $0.000<0.05$ \\
\hline & Kelantan & 983.5145 .43108 & Reject the null hypothesis \\
\hline
\end{tabular}

Table 5. Hypothesis testing - Cross-Industry

\begin{tabular}{|c|c|c|c|}
\hline & States & $\mathrm{N}$ Mean Std. D & Testing Mean Difference \\
\hline Shared meaning and interpretation & $\begin{array}{l}\text { Manufacture } \\
\text { Retailer } \\
\text { Wholesaler } \\
\text { Agriculture } \\
\text { Services } \\
\text { Total }\end{array}$ & $\begin{array}{c}1683.6622 .39754 \\
1313.6508 .36517 \\
313.8629 .30848 \\
14.0000 . \\
863.8227 .37351 \\
4173.7074 .38350\end{array}$ & $\begin{array}{l}\text { ndent-Samples-Kruskal-Wallis Test } \\
\qquad p \text { value: } 0.001<0.05\end{array}$ \\
\hline Shared values and norms & $\begin{array}{l}\text { Manufacture } \\
\text { Retailer } \\
\text { Wholesaler } \\
\text { Agriculture } \\
\text { Services } \\
\text { Total } \\
\end{array}$ & $\begin{array}{c}1683.8095 .72603 \\
1313.7042 .70629 \\
313.9194 .63701 \\
14.0000 . \\
863.7907 .61100 \\
4173.7812 .69050\end{array}$ & $\begin{array}{l}\text { ndent-Samples-Kruskal-Wallis Test } \\
\qquad p \text { value: } 0.228>0.05 \\
\text { Retain the null hypothesis }\end{array}$ \\
\hline Quality of business relationship & $\begin{array}{l}\text { Manufacture } \\
\text { Retailer } \\
\text { Wholesaler } \\
\text { Agriculture } \\
\text { Services } \\
\text { Total } \\
\end{array}$ & $\begin{array}{c}1683.9385 .60039 \\
1313.8422 .61717 \\
314.0430 .41715 \\
13.6667 . \\
863.9186 .45929 \\
4173.9113 .56801\end{array}$ & $\begin{array}{l}\text { ndent-Samples-Kruskal-Wallis Test } \\
\qquad p \text { value: } 0.154>0.05 \\
\text { Retain the null hypothesis }\end{array}$ \\
\hline Trust among key business players & $\begin{array}{l}\text { Manufacture } \\
\text { Retailer } \\
\text { Wholesaler } \\
\text { Agriculture } \\
\text { Services } \\
\text { Total } \\
\end{array}$ & $\begin{array}{c}1683.6920 .52766 \\
1313.6240 .57376 \\
313.5565 .28657 \\
13.7500 \\
863.7587 .46723 \\
4173.6745 .51828\end{array}$ & $\begin{array}{l}\text { dent-Samples-Kruskal-Wallis Test } \\
\text { p value: } 0.068>0.05\end{array}$ \\
\hline Length of business relationships & $\begin{array}{l}\text { Manufacture } \\
\text { Retailer } \\
\text { Wholesaler } \\
\text { Agriculture } \\
\text { Services } \\
\text { Total } \\
\end{array}$ & $\begin{array}{c}1683.7604 .66755 \\
1313.7366 .68593 \\
313.9597 .57044 \\
13.7500 \\
863.6686 .82287 \\
4173.7488 .70177\end{array}$ & $\begin{array}{l}\text { ndent-Samples-Kruskal-Wallis Test } \\
\qquad p \text { value: } 0.482>0.05 \\
\text { Retain the null hypothesis }\end{array}$ \\
\hline Network ties & $\begin{array}{l}\text { Manufacture } \\
\text { Retailer } \\
\text { Wholesaler } \\
\text { Agriculture } \\
\text { Services } \\
\text { Total } \\
\end{array}$ & $\begin{array}{c}r 1683.9889 .49684 \\
1313.9237 .53900 \\
313.8940 .36695 \\
14.0000 . \\
863.9236 .37872 \\
4173.9479 .47970 \\
\end{array}$ & $\begin{array}{l}\text { ndent-Samples-Kruskal-Wallis Test } \\
\qquad p \text { value: } 0.844>0.05 \\
\text { Retain the null hypothesis }\end{array}$ \\
\hline Network density & $\begin{array}{l}\text { Manufacture } \\
\text { Retailer } \\
\text { Wholesaler } \\
\text { Agriculture }\end{array}$ & $\begin{array}{c}1683.3165 .76401 \\
1313.2557 .67631 \\
313.2097 .60548 \\
14.3333\end{array}$ & $\begin{array}{l}\text { ndent-Samples-Kruskal-Wallis Test } \\
\qquad p \text { value: } 0.233>0.05\end{array}$ \\
\hline & & 357 & \\
\hline
\end{tabular}




\begin{tabular}{|c|c|c|c|}
\hline & $\begin{array}{l}\text { Services } \\
\text { Total }\end{array}$ & $\begin{array}{r}863.1764 .73180 \\
4173.2630 .72029\end{array}$ & Retain the null hypothesis \\
\hline & Manufacture & r1683.7359.49311 & ndent-Samples-Kruskal-Wallis Test \\
\hline & Wholesaler & 313.8911 .40018 & \\
\hline Cognitive social capital & Agriculture & 14.0000 & p value: $0.028<0.05$ \\
\hline & Services & 86 3.8067.39975 & Reject the null hypothesis \\
\hline & Total & 4173.7443 .46659 & \\
\hline & $\begin{array}{l}\text { Manufacture } \\
\text { Retailer }\end{array}$ & $\begin{array}{r}1683.7285 .40710 \\
1313.6672 .43589\end{array}$ & ndent-Samples-Kruskal-Wallis Test \\
\hline Social capital & Wholesaler & 313.7653 .27254 & $p$ value: $0.118>0.05$ \\
\hline & Agriculture & 13.9630 . & \\
\hline & $\begin{array}{l}\text { Services } \\
\text { Total }\end{array}$ & $\begin{array}{r}863.1129 .33930 \\
4173.7093 .39482\end{array}$ & Retain the null hypothesis \\
\hline
\end{tabular}

Hypothesis testing is done using the Independent-Samples-Kruskal-Wallis Test, which determines if there is a statistically significant difference between two or more groups of an independent variable on the dependent variable.

Based on the analysis, the distribution of network density is the same across states in Malaysia with no statistically significant difference. Distribution of shared meaning and interpretation is highest in the state of Johor with a mean value of 3.8434 , followed by Perak at 3.8409 while the state of Kelantan is the lowest at a mean value of 3.4719. The distribution of shared values and norms is noted to be high in Penang with a mean value of 4.1250 and the lowest in the state of Kelantan with a mean value of 3.4566. For the distribution of quality of business relationship, once again, the state of Penang has the highest mean value at 4.2111, while the state of Kelantan is at the lowest at 3.5680. The state of Johor has the highest mean value of 3.8157 and Kelantan has the lowest at 3.4388 for trust among key business players. In terms of length of business relationship, entrepreneurs in the state of Penang have the highest mean value at 4.0083 and entrepreneurs from the state of Kelantan scored the lowest with 3.4515 as the mean value. The state of Johor has the highest mean value for distribution of network ties with a mean value of 4.0866 with Terengganu scoring the lowest at 3.8180. For cognitive social capital, the state of Penang is reported to have the highest mean value of 3.9542 , while the state of Kelantan scored the lowest with a mean value of 3.4643. Overall, the distribution of social capital is not the same across the states in Malaysia. The state of Penang has a higher social capital compared to the other states such as Perak, Selangor, Johor, Kelantan, and Terengganu. In general, the state of Kelantan has the lowest level of social capital. The mean value for the distribution of social capital is 3.8989 for Penang, 3.8137 for Johor, 3.7659 for Selangor, 3.7530 for Perak, 3.6895 for Terengganu, and 3.5145 for Kelantan.

The next 8 hypotheses tested the distribution of social capital across industries. This study included manufacturing, retailing, wholesale, agriculture, and services. Based on the analysis, the distribution of shared values and norms, quality of business relationship, trust among key business players, length of business relationship, network ties, network density, and social capital is the same across the industries. It is noted that the distribution of shared meaning and interpretation and cognitive social capital is not the same across the industries. The mean value for distribution of shared meaning and interpretation is highest in agriculture, followed by the wholesale industry at 4.0 and 3.8629 , respectively. Manufacturing and retailing have the lowest level of shared meaning and interpretation at the mean values of 3.6622 and 3.6508 , respectively. For cognitive social capital, the mean value is the highest in the agriculture industry with a mean value of 4.0000 and the lowest in the retailing industry.

\section{Conclusion}

Social capital plays a crucial role in entrepreneurship and is linked to economic growth. Network relationships are important to entrepreneurs as they provide access to resources that are an important component in the entrepreneurial process. The findings of this study suggest that the distribution of social capital is more balanced across industries such as manufacturing, retailing wholesale, agriculture, and services. On the other hand, at the country level, the distribution of social capital is noted to be dissimilar among the states of Penang, Perak, Selangor, Johor, Terengganu, and Kelantan. The findings of social capital distribution across states are in line with the findings of Fazio and Lavecchia (2013). The reason for the unequal distribution of social capital across states in Malaysia is not determined in this research.

It is noted that the states of Kelantan and Terengganu are the lowest in social capital mean values. Relational and cognitive dimensions of social capital which consist of shared meaning and interpretation, shared values and norms, quality of business relationship, trust among key business players, and length of business relationship should be the 
elements to be focused on to increase social capital in both these states. Policy makers should make implementations in order to increase the social capital of the states with a low level of social capital as social capital is linked to enterprise performance and economic development. A better-distributed social capital can result in a balanced economic development.

\section{References}

Ahlin, C. \& Townsend, R. M. 2007. Using repayment data to test across models of joint liability lending. The Economic Journal, 117 (517), pp. 11-51.

Baker, W. 2010. Achieving success through social capital. [San Francisco, Calif.]: Jossey-Bass.

Bennet, D. and Richardson, P. 2005. Building Relationships and Social Capital Development. Paper presented at the 50th ICSB World Conference, Washington DC

Burt, R. S. 1992. Structural Holes: The Social Structure of Competition. Cambridge: Harvard University Press

Burt, R. S. 1995. The Social Structure of Competition \& Formalizing the Argument, in Structural Holes: The Social Structure of Competition. Cambridge, MA: Harvard University Press

Buttner, H; Rosen, B. 1998. Bank loan officer's perceptions of the characteristics of men and women and successful entrepreneurs. Journal of Business venturing, Vol.3 No.3, pp. 249-258.

Carey, S., Lawson, B., \& Krause, D. 2011. Social capital configuration, legal bonds and performance in buyer-supplier relationships. Journal Of Operations Management, 29(4), 277-288. doi:10.1016/j.jom.2010.08.003

Casson, M. \& Della Giusta, M. 2007. Entrepreneurship and social capital analysing the impact of social networks on entrepreneurial activity from a rational action perspective. International Small Business Journal, 25 (3), pp. 220-244

Chen, Y., Zhang, Y., \& Fey, C. 2011. When collaborative HR practices may not work well: the moderating role of social capital in the Chinese life insurance industry. The International Journal Of Human Resource Management, 22(2), 433-456. doi:10.1080/0 9585192.2011 .540164

Cook, L. 2011. Inventing social capital: Evidence from African American inventors, 1843 - 1930. Explorations In Economic History, 48(4), 507-518. doi:10.1016/j.eeh.2011.05.003

Department of Statistics 2011. Economic Census, Profile of Small and Medium Enterprise. Malaysia: Department of Statistics.

Elly, Y. 2010. Impact of Embeddedness in Co-ethnic and Non Co-ethnic Network on Business Performance: Evidence from Chinese Immigrant Entrepreneurs in Australia, Master Dissertation, Queensland University of Technology.

Fazio, G., \& Lavecchia, L. 2013. Social Capital Formation across Space: Proximity and Trust in European Regions. International Regional Science Review, 36(3), 296-321. doi:10.1177/0160017613484928

Gailey, R. 2010. Social Capital and Economic Empowerment: A longitudinal analysis of the relationship between changes in the value of accumulate assets and measures of social capital among rural South African women (PhD). University of San Diego.

Gauntlett, D. 2011. Making is connecting. Cambridge, UK: Polity Press.

Grootaert, C. 1998. Social Capital: The Missing Link?.Social Capital Initiative Working Paper No. 3. Washington, D.C: World Bank.

Hanafi, N. 2012. Learning orientation, entrepreneurial orientation, competitive advantage and business performance of women-owned SMEs in Malaysia, Unpublished DBA dissertation, UUM, Kedah

Helliwell, J.F., and R.D. Putnam 1999. Education and Social Capital. NBER Working Paper W7121. Cambridge: National Bureau of Economic Research.

Hoffmann, S., \& Putnam, R. 2003. Democracy in Flux: The Evolution of Social Capital in Contemporary Society. Foreign Affairs, 82(1), 169. doi: $10.2307 / 20033465$

Jayawarna, D., Jones, O., \& Macpherson, A. 2011. New business creation and regional development: Enhancing resource acquisition in areas of social deprivation. Entrepreneurship \& Regional Development, 23(9-10), 735-761. doi:10.1080/08985626.2010. 520337

Kickul, J., Gundry, L., \& Sampson, S. 2007. Women Entrepreneurs Preparing for Growth: The Influence of Social Capital and Training on Resource Acquisition. Journal Of Small Business \& Entrepreneurship, 20(2), 169-181. doi:10.1080/08276331.2007.10593393

Koh, T. (2010). The effects of social capital on construction project success: exploring the mediating role of project learning, PhD Dissertation. University of Hong Kong.

Krishna, A. 2008. Social capital and economic development. In: Castiglione, D., Deth, J. \& Wolleb, G. eds. (2008). The handbook of social capital. New York: Oxford University Press.

Mercy, A. 2013. The Influence Of Financial and Knowledge Factors On Smes Kibs (Knowledge intensive business services) New Market Pioneering In Developing Economies, PhD Dissertation, University of Essex.

Moran, P. 2005. Structural vs. relational embeddedness: social capital and managerial performance. Strat. Mgmt. J., 26(12), 11291151. doi: $10.1002 / \mathrm{smj} .486$

Nahapiet, J., \& Ghoshal, S. 1998. Social capital, intellectual capital, and the organizational advantage. Academy Of Management Review, 23(2), 242-266. doi:10.5465/amr.1998.533225

Narayan, D., Jones, V., \& Woolcock, M. (2003). Measuring Social Capital. World Bank Policy Research Working Paper No. 2148). Washington, D.C: World Bank

Neira, I., Portela, M., Cancelo, M., \& Calvo, N. 2013. Social and human capital as determining factors of entrepreneurship in the Spanish Regions. Investigaciones Regionales, 26, 115-139 
Park, Y., Shin, J. \& Kim, T. 2010. Firm size, age, industrial networking, and growth: a case of the Korean manufacturing industry. Small Business Economics, 35 (2), pp. 153-168.

Parts, E. 2013. The Dynamics and Determinants of Social Capital in the European Union and Neighbouring Countries. SSRN Journal. doi:10.2139/ssrn.2336016

Percoco, M. 2012. Entrepreneurship, Social Capital and Institutions: Evidence from Italy. Spatial Economic Analysis, 7(3), 339-355. doi:10.1080/17421772.2012.694144

Ponzetto, G., \& Troiano, U. 2014. Social Capital, Government Expenditures, and Growth. SSRN Journal. doi:10.2139/ssrn.2142548

Putnam, R., Leonardi, R., \& Nanetti, R. 1993. Making democracy work. Princeton, N.J.: Princeton University Press.

Rochelle, R. 2011. Making Their Way in the Mainstream: Indigenous Entrepreneurs, Social Capital and Performance in Toronto's Marketplace. PhD Dissertation, University of Toronto.

Schilling, M. A. \& Phelps, C. C. 2007. Interfirm collaboration networks: the impact of large-scale network structure on firm innovation. Management Science, 53 (7), pp. 1113-1126.

Tsai, W. \& Ghoshal, S. 1998. Social capital and value creation: the role of intrafirm networks. Academy Of Management Journal, 41 (4), pp. 464-476.

Turner, J. T. 2011. Social capital: measurement, dimensional interactions, and performance implications. PhD Dissertation. The Graduate School of Clemson University

Tzanakis, M. 2013. Social capital in Bourdieu's, Coleman's and Putnam's theory: empirical evidence and emergent measurement issues. Educate, 13(2), 2 - 23.

Van Oorschot, W., Arts, W., \& Gelissen, J. 2006. Social Capital in Europe: Measurement and Social and Regional Distribution of a Multifaceted Phenomenon. Acta Sociologica, 49(2), 149-167. doi:10.1177/0001699306064770

Weick, K. E. 1995. Sensemaking in organizations. Thousand Oaks, CA: Sage 